\title{
Storage Temperature and Storage Duration Affect Fruit and Oil Quality of Coratina, Manzanillo and Picual Olives
}

\author{
Nermeen I. EL- Naggar ${ }^{1}$ and Ragaa M. El-Saedy ${ }^{2}$
}

\begin{abstract}
During 2008 and 2009 seasons, Coratina, Manzanillo and Picual olive fruits were stored at 5,10 and $20^{\circ} \mathrm{C}$ with 85 - $90 \%$ relative humidity. All olive cvs were stored only for one week at $20^{\circ} \mathrm{C}$ with the loss of fruit appearance. Coratina fruits were the most tolerant to chilling injury and no internal browning was observed in fruit flesh of all cvs during the storage period. Storage temperature had significant effect on fruit weight loss where the stored fruits at $10^{\circ} \mathrm{C}$ lost more than 3 folds of those stored at $5^{\circ} \mathrm{C}$. By the progress of the storage period, fruit weight loss increased while the moisture values declined and the stored fruits at $5^{\circ} \mathrm{C}$ had significantly higher moisture content. Coratina olives significantly contained the highest oil content (26.81 and 28.10 \%) followed by Picual (25.21 and $26.44 \%$ ) then Manzanillo fruits (24.25 and $25.55 \%$ ). Oil content decreased significantly with increasing the storage temperature and time. Palmitic, arachidic, oleic, palmitoleic and linoleic fatty acids were not affected by the storage temperature. Myristic fatty acid increased in Coratina fruits stored at $10^{\circ} \mathrm{C}$. Stearic acid values of Coratina and Manzanillo declined by the end of the storage period while that of Picual increased. Myristic, palmitoleic and linoleic fatty acids increased with the progress of the storage period while arachidic and oleic fatty acids decreased. Linolenic acid content of Coratina fruits increased in the third week at 5 and $10^{\circ} \mathrm{C}$ then decreased with the progress of the storage period. Coratina had the highest linolenic content at the third week while Manzanillo had the highest content after 4 weeks at $5^{\circ} \mathrm{C}$. There was no effect of the storage temperature or period on fruit lipids content but generally, the fruits that were stored at $20^{\circ} \mathrm{C}$ contained lower values.
\end{abstract}

\section{INTRODUCTION}

Olive (Olea europea L.) is one of the most important and popular fruit crops in Egypt and its total area exceeded rapidly during the last years in new lands. Olive fruits are used for oil extraction or pickling. The beneficial health effects of olive oil are due to both its high content of monounsaturated fatty acids and its high content of antioxidative substances. Studies have shown that olive oil offers protection against heart disease by controlling LDL (bad) cholesterol levels while raising HDL (good) cholesterol levels. Due to the limited oil extraction capacities of the industrial facilities, processing of olives is not well synchronized with harvest. Therefore after harvest, olives might be piled in heaps and stored at ambient temperatures for up to several weeks before processing for oil extraction and during this period the greatest deterioration takes place. Pressure within the olive pile during storage can cause fluid secretion from the fruit that can provide an optimum medium for growth of fungi and bacteria. Furthermore, heat production from respiration activity may accelerate the deterioration of the fruits and eventually cause the breakdown of cell structure. Oil extracted from these damaged olives can be high in acidity and low in stability and can develop a high content of volatile acids (acetic or butyric) that causes a characteristic musty smell and the resultant oil requires refining resulting in higher costs and loss of market value (Ager et al., 1998 \& 1999; Garcia and Streif, 1991; Garcia et al., 1996; Gutierrez et al., 1992 and Olias and Garcia, 1997). Therefore, storage of fresh olives is more desirable and could allow a more orderly flow to the processing plant (Kader et al., 1989). The possibility of extending the length of storage of olives before oil extraction could increase the yield of good quality oil (Petruccioli and Parlati, 1987). The storage below $5^{\text {? }} \mathrm{C}$ causes chilling injury $(\mathrm{CI})$ and thus the minimum safe storage temperature is $5^{\circ} \mathrm{C}$ and the $\mathrm{CI}$ depends on time, temperature, cultivar, maturity and atmospheric composition (Maxie, 1998 and Kader et al., 1990). The objective of this study was to evaluate intercultivar differences and to identify the optimum preprocessing storage temperature to maintain fruit and oil quality of Coratina, Manzanillo and Picual olive fruits.

\section{MATERIALS AND METHODS}

The present study was carried out during 2008 and 2009 seasons on Coratina, Manzanillo and Picual olive fruits harvested from El-Shrouq private orchard at Cairo-Alexandria desert road $(74 \mathrm{~km}$ from Cairo, 6 October governorate). Sound selected fruits were packed in plastic open boxes (5kg of each) and transported to the Postharvest Center of Horticulture Crops, Faculty of Agriculture, Alexandria University.

\footnotetext{
${ }^{1}$ Dep.Plant. Prod.(Pomology), Institute of Efficient Productivity, )

Zag. Unv.

${ }^{2}$ Maamoura Botanical Garden, Alex.Hort. Res., Agric. Res.

Center, Giza Egypt

Received April 22, 2010, Accepted May 24, 2010
} 
The initial fruit quality (average of 30 fruits of each cultivar) was determined (table 1) then the fruits were

Table 1. The initial quality of Coratina, Manzanillo and Picual olive fruits during 2008 and 2009 seasons

\begin{tabular}{lcccccc}
\hline \multicolumn{1}{c}{ Parameter } & \multicolumn{2}{c}{ Coratina } & \multicolumn{2}{c}{ Manzanillo } & \multicolumn{2}{c}{ Picual } \\
\cline { 2 - 7 } & $\mathbf{2 0 0 8}$ & $\mathbf{2 0 0 9}$ & $\mathbf{2 0 0 8}$ & $\mathbf{2 0 0 9}$ & $\mathbf{2 0 0 8}$ & $\mathbf{2 0 0 9}$ \\
\hline Fruit wt. (gm) & 4.03 & 4.16 & 5.06 & 4.56 & 3.57 & 3.37 \\
Fruit size: & & & & & & \\
Length(cm) & 2.17 & 2.23 & 2.40 & 2.30 & 2.25 & 2.27 \\
Diameter(cm) & 1.63 & 1.83 & 1.97 & 1.97 & 1.57 & 1.73 \\
Seed wt. (gm) & 0.85 & 0.90 & 0.82 & 0.76 & 0.79 & 0.80 \\
Flesh wt. (gm) & 3.18 & 3.26 & 4.24 & 3.80 & 2.78 & 2.57 \\
Flesh/fruit (\%) & 78.91 & 78.37 & 83.79 & 83.33 & 77.87 & 76.26 \\
\hline
\end{tabular}

stored at 5,10 and $20^{\circ} \mathrm{C}$ with $85-90 \%$ relative humidity. The physio-chemical properties of the stored fruits were followed up in 7 days intervals (oil properties were followed up after $0,1,3,4,6,7$ weeks) throughout the storage period as follow.

Five nets of 100 fruits of each cv. were labeled then weighed to calculate fruit weight loss percent during the storage period in relation to its original weights. Another same 5 nets were labeled to observe the change in fruit quality such as shrinkage, visual color changes, rot incidence and the chilling injury symptoms.

Moisture content (\%) was determined by drying three recorded weights of fruit flesh from each treatment. Subsequent periodical weight determinations were carried out to obtain a constant dry weight then the percentage moisture content was calculated in relation to the initial recorded weight.

External color of the fruits was estimated visually and measured with Menolta colorimeter. L, a and b values were used to calculate the hue angle of each fruit in the sample of each treatment according to Mclellan et al., (2007) as follows: $\mathrm{Hue}^{\circ}=180+\operatorname{Arctan}(\mathrm{b} / \mathrm{a})$.

Total lipids content of olive fruits was determined according the method of Folch et al., (1957).

Preparation of fatty acid methyl esters from lipids (olive oil) was performed according to the procedure of Radwan (1978) and the oil percent was recorded. Analysis of fatty acids was carried out by gas liquid chromatography (GLC) according to AOAC (1984).

The termination of the experiment was done by the incidence of chilling injury symptoms and by the loss of good fruit appearance. All data obtained were statistically analyzed according to the methods described by Snedecor and Cochran (1980). The individual comparisons were carried out by using the Least Significant Difference (LSD) according to SAS Institute (1985). Simple regression coefficient $\left(r^{2}\right)$ between storage period and studied properties was calculated using SAS program (1985).

\section{RESULTS AND DISCUSSION}

\section{Visual fruit quality and storagability:}

Manzanillo had the highest fruit weight and size with the highest flesh/fruit percent. The importance of olive fruit dimensions is determining the aperture size of separating machines. The variation of fruit mass, length and width of olive fruits could be due to different cultivars, environmental conditions and nutritional status of orchards. The higher flesh/pit ratio is a desired fruit property in olive (Ozturk et al., 2009).

All the studied olive cvs were stored only for one week at $20^{\circ} \mathrm{C}$ with the loss of fruit good appearance due to shrinkage and purple pigment accumulation (ripening) in Coratina and Manzanillo fruits while Picual fruits remained green. After that period at $20^{\circ} \mathrm{C}$, 2.70, 5.41, 8.11 and $16.22 \%$ of Coratina fruits (average of two seasons) turned to $100,75,50$ and $25 \%$ skin purple color, respectively. The corresponding percentages of purple colored fruits for Manzanillo cv were $19.75,9.26,14.82$ and $19.26 \%$, respectively.

The initial appearance of purple color was at $10^{\circ} \mathrm{C}$ on Coratina fruits after one week. On the other hand, after the same period at $5^{\circ} \mathrm{C}$ chilling injury symptoms started to be observed on Manzanillo fruit skin as small brown spots. Those symptoms increased with the progress of cold storage at $5^{\circ} \mathrm{C}$ to reach the percent of $50 \%$ of fruit number at the end of the storage period (4 weeks). Picual fruits showed more tolerance to chilling injury where the initial symptoms appeared after 3 weeks at $5^{\circ} \mathrm{C}$ on few fruits and increased slowly to reach $50 \%$ at the end of the storage period (6 weeks). Coratina fruits were the most tolerant to chilling injury where the symptoms appeared on $50 \%$ of the fruits after a longest period of 7 weeks at $5^{\circ} \mathrm{C}$. No internal browning was observed in fruit flesh of all cvs during the storage period.

Fruits stored at $10^{\circ} \mathrm{C}$ were safe from chilling injury but it suffered from water loss and shrinkage appearance on the fruits which reached the percent of 
$50 \%$ after 3 weeks for Manzanillo and Picual and after 4 weeks for Coratina.

A high level of respiration determines two undesirable effects, a shorter commercial life for the stored product and a loss in weight and nutritional value, because this process consumes energy metabolites such as sugars, lipids or organic acids. Furthermore, refrigeration delays the deterioration activity of the pathogens (Garcia and Yousif, 2006). Storage of olives at room temperature led to their deterioration after 15 days of storage (Clodoveo et al., 2007). In olives, decreasing the temperature from 18 to $5^{\circ} \mathrm{C}$ led to chilling injury appearance (Garcia and Streif, 1991). The cause of chilling injury has been attributed to a non programmed accumulation of succinic acid in the Krebs cycle. Succinic-dehydrogenase should be more affected by a low temperature than the other enzymes of this metabolic system and its toxic substrate would destroy the fruit cell (Kader, 1985). At the same time, low temperature could affect the permeability of the plasmatic membrane, altering the physical properties of its main constituent, the phospholipids (Garcia and Yousif, 2006).

Chilling injury which can be a major cause of deterioration in fresh olives stored before processing, is described as internal browning around the pit or skin at advanced stages (Kader et al., 1996; Kiritsakis et al., 1998 and Agar et al., 1999). Chilling injury symptoms were observed in mature-green Manzanillo olives when stored at 0 and $2.5^{\circ} \mathrm{C}$ after 2 and 5 weeks respectively, whereas those stored at 5-7 ${ }^{\circ} \mathrm{C}$ had no visible symptoms of chilling injury (Kader et al., 1990 and Agar et al., 1999).

\section{Skin color changes (hue angle):}

Storage temperature in general, had a significant effect on skin color presented as hue (table 2) of Coratina and Manzanillo fruits where the stored fruits at $20^{\circ} \mathrm{C}$ for one week had the highest hue ${ }^{\circ}$ values in the two seasons which reflect the skin color changes from green to bluish-purple.

On the other hand, no significant changes were obtained with Picual fruits which remained green. The stored fruits at $10^{\circ} \mathrm{C}$ had higher hue ${ }^{\circ}$ degrees which changed significantly with the storage duration. Fruit skin color is considered to be the most important index of olive external quality and an important consideration to determine maturity of fruits (Ozturk et al., 2009). A $90^{\circ}$ hue angle represents yellow, $180^{\circ}$ represents bluishgreen, $270^{\circ}$ represents blue and $0^{\circ}$ represents reddishpurple (McGuire, 1992). Agar et al., (1999) reported that Manzanillo olives stored at $20^{\circ} \mathrm{C}$ had significant poorer color than fruit from the other treatments.

Fruit weight loss and moisture content (\%):
Storage temperature had significant effect on weight loss of Coratina, Manzanillo and Picual fruits where the stored fruits at $20^{\circ} \mathrm{C}$ loss of its initial weight more than $16 \%$ in Coratina, more than $12 \%$ in Manzanillo and more than $11 \%$ in Picual (table 3). The stored fruits at $10^{\circ} \mathrm{C}$ lost more than 3 folds of those stored at $5^{\circ} \mathrm{C}$. By the progress of storage period fruit weight loss of all cvs increased significantly $\left(\mathrm{r}^{2}\right.$ values were highly significant).

Ager et al., (1998) showed that weight loss increased with storage time and ranged between 0.6 (Sevillano) and $1.5 \%$ (Manzanillo) in black-ripe olives which were stored at $5^{\circ} \mathrm{C}$, while it ranged between 2.3 and $3 \%$ in those stored at $20^{\circ} \mathrm{C}$ for 2 weeks. Castellano et al., (1993) reported that higher weight loss at $20^{\circ} \mathrm{C}$ might be partially due to fungal decomposition of olives resulting in the leakage of cell fluids as well as transpiration.

The initial moisture content of olive fruits in this work ranged from 74.48 to $76.05 \%$. Those values declined significantly after 1 week when the fruits were stored at $20^{\circ} \mathrm{C}$ and there was no significant difference between fruits that were stored at 5 and $10^{\circ} \mathrm{C}$ (table 4). In the second week and during the storage period the stored fruits at $5^{\circ} \mathrm{C}$ had significantly higher moisture content than those stored at $10^{\circ} \mathrm{C}$. Fruit moisture content of all cvs decreased $\left(r^{2}\right.$ values were not significant) with the progress of the storage time.

Ager et al., (1998) reported that water content at harvest was 67.9, 60.5, 52.5 and 61.2 \% in Ascolano, Manzanillo, Mission and Sevillano olives, respectively. There were no significant differences in water content of black-ripe olives over storage time. Kiritsakis, (1998) recorded that water in olive fruit served as solvent for organic acids, tannins, oleuropein and other water soluble components of the fruits and its content was based on stage of maturity, variety, climate condition, irrigation and soil moisture.

\section{Fruit oil content:}

Significantly in 2008 and 2009 seasons, Coratina olives contained the highest oil content (26.81 and $28.10 \%$ ) followed by Picual (25.21 and $26.44 \%$ ) then Manzanillo (24.25 and $25.55 \%$ ) fruits (table 5). Oil content decreased significantly with the increasing of the storage temperature especially at $20^{\circ} \mathrm{C}$ where the above initial values decreased to 18.33 and $18.52 \%$ in Coratina, 16.44 and $16.77 \%$ in Picual and to 15.66 and $16.93 \%$ in Manzanillo fruits respectively in 2008 and 2009 seasons. With the progress of the storage period, oil content of the three cvs decreased and $r^{2}$ values were highly significant. 


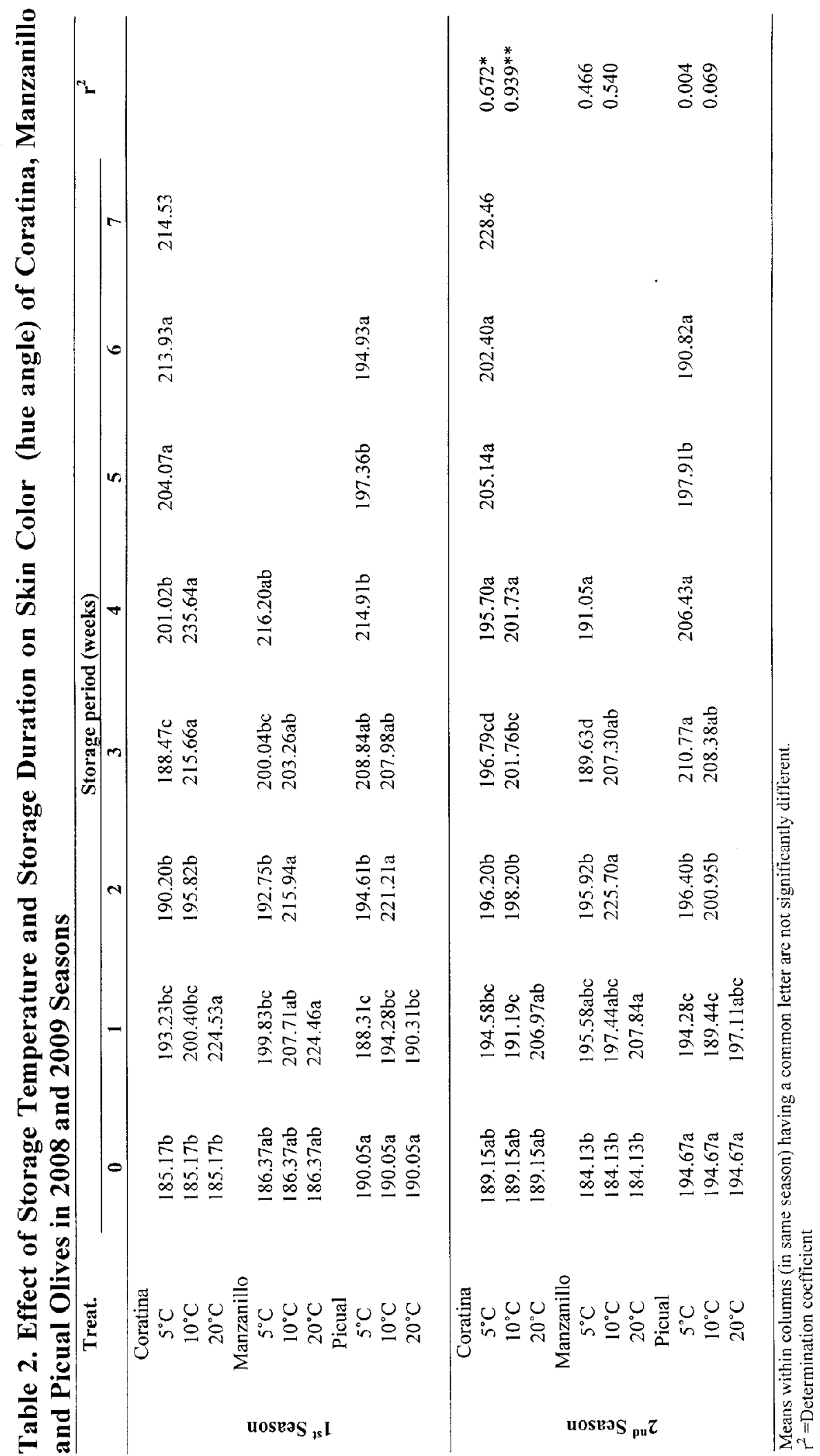




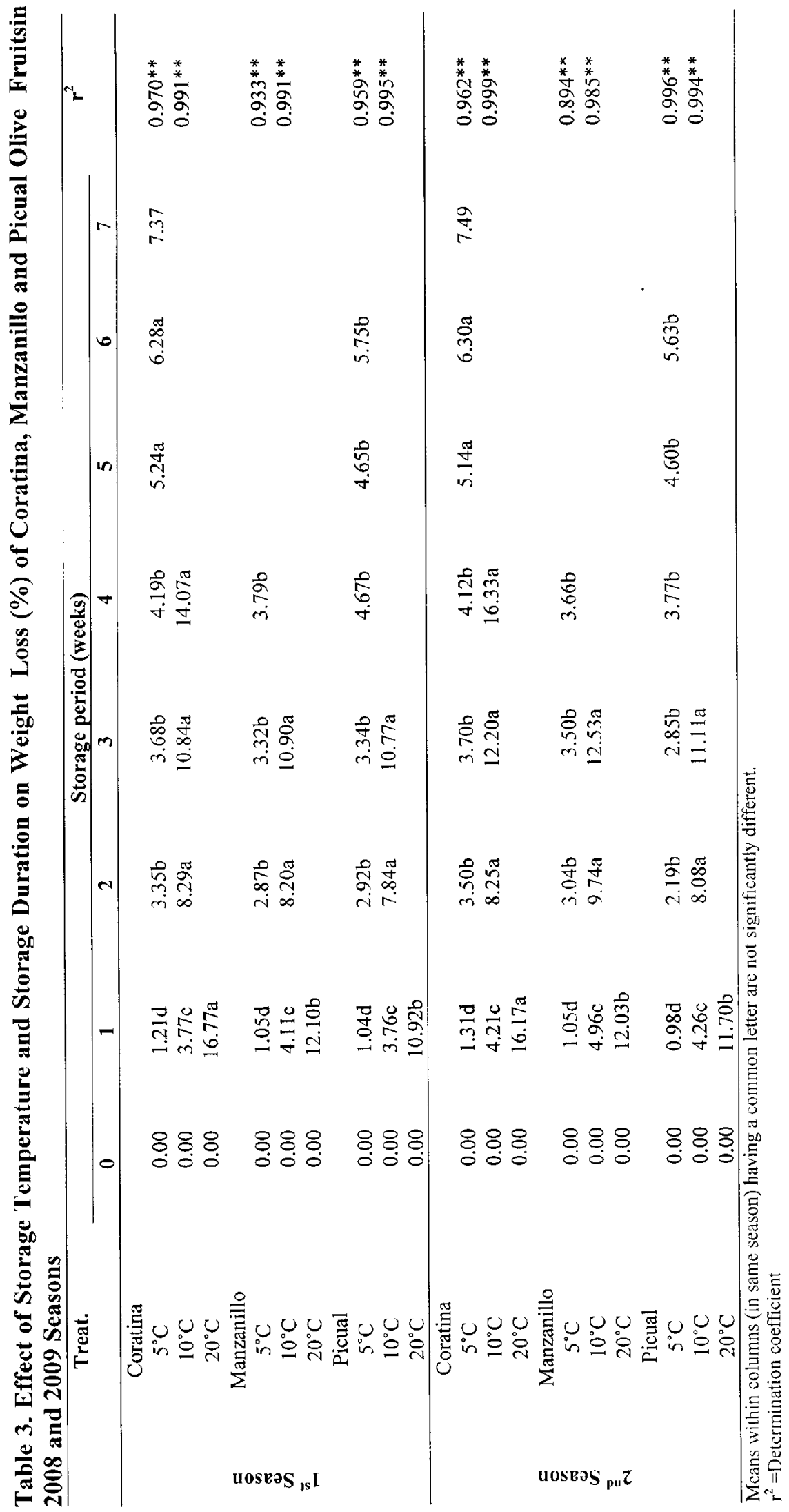




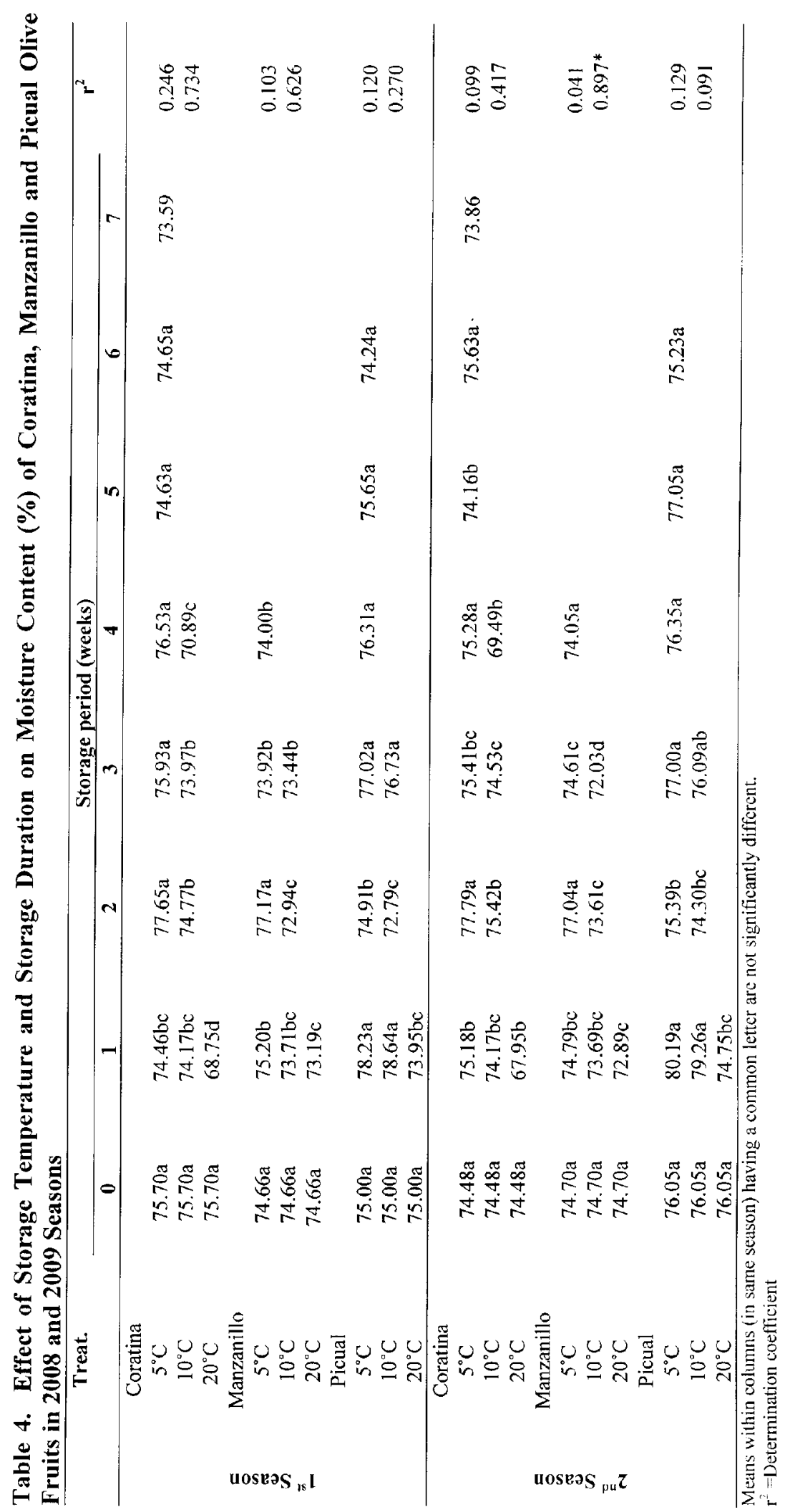




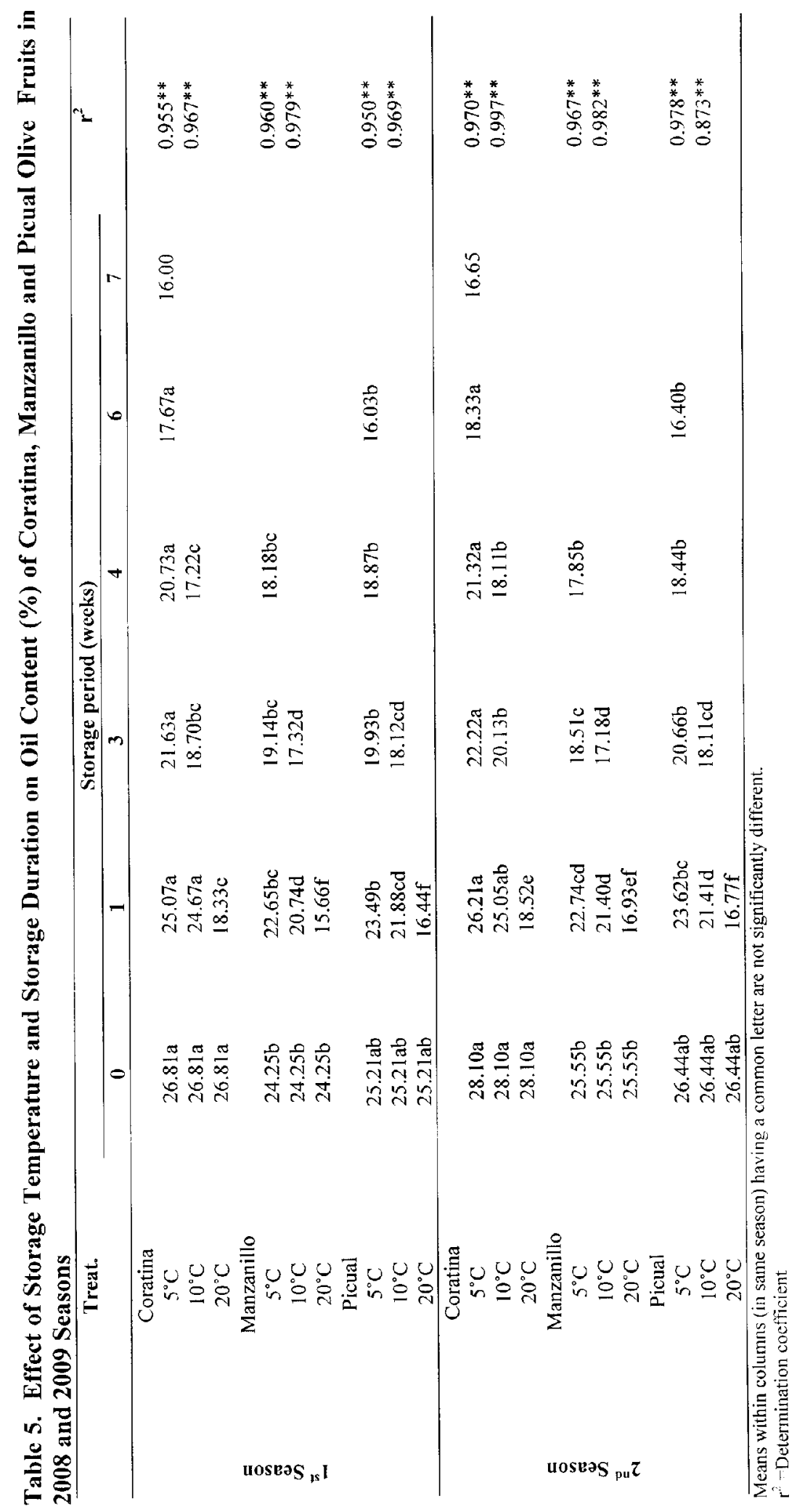


Ager et al., (1998) found that the oil content of olive fruits remained unchanged during storage at $5^{\circ} \mathrm{C}$. Black ripe Ascolano and Sevillano olives contained 28.5 and $28.8 \%$ oil, respectively, whereas Manzanillo and Mission olives contained 33.3 and $37.7 \%$, respectively. Oil content of black ripe Manzanillo and Ascolano olives stored at $20{ }^{\circ} \mathrm{C}$ for 2 weeks was 29.9 and $26.5 \%$, respectively, which was lower than the initial values and those of olives stored at $5{ }^{\circ} \mathrm{C}$, whereas oil content of other cvs remained unchanged.

The above results are associated also with those of Raie and Latif (1982); Gutierrez et al., (1992) and Ager et al., (1999).

\section{Fatty acid composition:}

\section{a- Saturated fatty acids:}

The initial total percent of saturated fatty acids in Coratina, Manzanillo and Picual olive fruits respectively were $23.94,25.23$ and $23.53 \%$ in the first season and 26.54, 25.78 and $25.56 \%$ in the second one. Those percentages mainly included the values of palmitic, stearic and arachidic acids.
The highest percent was for palmitic acid which initially was (an average of two seasons) $20.27 \%$ in Coratina, $20.93 \%$ in Manzanillo and $21.21 \%$ in Picual fruits (table 6). Those initial values were not affected by the storage temperatures (fruits were stored at $20^{\circ} \mathrm{C}$ slightly had highest values) or by the storage period $\left(\mathrm{r}^{2}\right.$ values were not significant). Agar et al., (1998) reported that palmitic acid is the primary saturated fatty acid in olives. Manzanillo (14.3\%) and Ascolano (13.9\%) olives had a significantly higher content of palmitic acid than Mission (11.2\%). Also, palmitic acid changed significantly over storage time. Agar et al., (1999) recorded that palmitic acid content in black-ripe Manzanillo olives was $15.2 \%$ at harvest and ranged between 13.7 and $14.9 \%$ during 6 weeks storage.

Stearic acid contents (table 7) as an average of the two seasons were 3.61, 3.89 and $2.83 \%$ for Coratina, Manzanillo and Picual olives, respectively. Those values of Coratina and Manzanillo declined by the end of the storage period while that of Picual increased Agar et al., (1999) showed that the stearic acid content of black-ripe Manzanillo ranged between 3.8 and $5.3 \%$ in air stored olives during 6 weeks storage.

Table 6. Effect of Storage Temperature and Storage Duration on Palmitic Acid (\%) of Coratina, Manzanillo and Picual Olive Fruits in 2008 and 2009 Seasons

\begin{tabular}{|c|c|c|c|c|c|c|c|c|}
\hline & Treat. & & & orage per & (weeks) & & & $\mathbf{r}^{2}$ \\
\hline & & $\mathbf{0}$ & 1 & 3 & 4 & 6 & 7 & \\
\hline & Coratina & & & & & & & \\
\hline & $5^{\circ} \mathrm{C}$ & $19.54 \mathrm{a}$ & $20.43 \mathrm{ab}$ & $17.62 d$ & $19.12 \mathrm{a}$ & $19.76 a$ & 19.41 & 0.004 \\
\hline & $10^{\circ} \mathrm{C}$ & $19.54 \mathrm{a}$ & $20.54 \mathrm{ab}$ & $21.58 \mathrm{abc}$ & $20.21 \mathrm{a}$ & & & 0.214 \\
\hline & $20^{\circ} \mathrm{C}$ & $19.54 \mathrm{a}$ & $21.19 \mathrm{ab}$ & & & & & \\
\hline$\tilde{0}$ & Manzanillo & & & & & & & \\
\hline E & $5^{\circ} \mathrm{C}$ & $20.44 a$ & $18.36 b$ & $19.92 \mathrm{c}$ & $19.31 \mathrm{a}$ & & & 0.070 \\
\hline 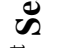 & $10^{\circ} \mathrm{C}$ & $20.44 a$ & $22.04 \mathrm{a}$ & $20.64 b c$ & & & & 0.013 \\
\hline$\stackrel{5}{=}$ & $20^{\circ} \mathrm{C}$ & $20.44 a$ & $19.24 \mathrm{ab}$ & & & & & \\
\hline & Picual & & & & & & & \\
\hline & $5^{\circ} \mathrm{C}$ & $19.95 \mathrm{a}$ & 19.39ab & $23.21 \mathrm{a}$ & $20.05 a$ & $20.94 a$ & & 0.077 \\
\hline & $10^{\circ} \mathrm{C}$ & $19.95 \mathrm{a}$ & $21.75 \mathrm{a}$ & $21.97 \mathrm{ab}$ & & & & 0.083 \\
\hline & $20^{\circ} \mathrm{C}$ & $19.95 \mathrm{a}$ & $21.22 \mathrm{a}$ & & & & & \\
\hline & Coratina & & & & & & & \\
\hline & $5^{\circ} \mathrm{C}$ & $20.99 a$ & $20.47 \mathrm{ab}$ & $20.62 a$ & $19.58 \mathrm{a}$ & $19.78 \mathrm{a}$ & 19.72 & 0.468 \\
\hline & $10^{\circ} \mathrm{C}$ & $20.99 a$ & $18.82 b$ & $21.14 \mathrm{a}$ & $19.70 \mathrm{a}$ & & & 0.033 \\
\hline & $20^{\circ} \mathrm{C}$ & $20.99 a$ & $20.80 \mathrm{ab}$ & & & & & \\
\hline อี & Manzanillo & & & & & & & \\
\hline छै & $5^{\circ} \mathrm{C}$ & $21.41 \mathrm{a}$ & $22.47 \mathrm{ab}$ & $21.43 \mathrm{a}$ & $20.93 a$ & & & 0.243 \\
\hline $\mathscr{\infty}$ & $10^{\circ} \mathrm{C}$ & $21.41 \mathrm{a}$ & $21.31 \mathrm{ab}$ & $21.63 \mathrm{a}$ & & & & 0.451 \\
\hline స & $20^{\circ} \mathrm{C}$ & $21.41 \mathrm{a}$ & $22.92 \mathrm{ab}$ & & & & & \\
\hline & Picual & & & & & & & \\
\hline & $5^{\circ} \mathrm{C}$ & $22.46 a$ & $20.53 \mathrm{ab}$ & $22.12 \mathrm{a}$ & $19.73 a$ & $20.77 \mathrm{a}$ & & 0.336 \\
\hline & $10^{\circ} \mathrm{C}$ & $22.46 a$ & $19.51 b$ & $21.44 \mathrm{a}$ & & & & 0.116 \\
\hline & $20^{\circ} \mathrm{C}$ & $22.46 \mathrm{a}$ & $24.05 \mathrm{a}$ & & & & & \\
\hline
\end{tabular}

Means within columns (in same season) having a common letter are not significantly different.

$\mathrm{r}^{2}=$ Determination coefficie 
Table 7. Effect of Storage Temperature and Storage Duration on Stearic Acid (\%) of Coratina, Manzanillo and Picual Olive Fruits in 2008 and 2009 Seasons

\begin{tabular}{|c|c|c|c|c|c|c|c|c|}
\hline & \multirow[t]{2}{*}{ Treat. } & \multicolumn{6}{|c|}{ Storage period (weeks) } & \multirow[t]{2}{*}{$\mathbf{r}^{2}$} \\
\hline & & $\mathbf{0}$ & 1 & 3 & 4 & 6 & 7 & \\
\hline \multirow{12}{*}{ 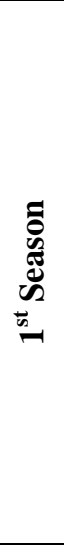 } & Coratina & & & & & & & \\
\hline & $5^{\circ} \mathrm{C}$ & $3.18 \mathrm{ab}$ & $2.61 \mathrm{ab}$ & $3.08 b c$ & $2.80 \mathrm{a}$ & $2.68 \mathrm{a}$ & 2.33 & 0.542 \\
\hline & $10^{\circ} \mathrm{C}$ & $3.18 \mathrm{ab}$ & $3.07 \mathrm{ab}$ & $3.97 \mathrm{a}$ & $2.53 \mathrm{a}$ & & & 0.052 \\
\hline & $20^{\circ} \mathrm{C}$ & $3.18 \mathrm{ab}$ & $2.54 \mathrm{~b}$ & & & & & \\
\hline & Manzanillo & & & & & & & \\
\hline & $5^{\circ} \mathrm{C}$ & $4.20 \mathrm{a}$ & $2.90 \mathrm{ab}$ & $2.72 \mathrm{c}$ & $2.81 \mathrm{a}$ & & & 0.646 \\
\hline & $10^{\circ} \mathrm{C}$ & $4.20 \mathrm{a}$ & $3.35 \mathrm{a}$ & $3.75 \mathrm{ab}$ & & & & 0.280 \\
\hline & $20^{\circ} \mathrm{C}$ & $4.20 \mathrm{a}$ & $2.76 \mathrm{ab}$ & & & & & \\
\hline & Picual & & & & & & & \\
\hline & $5^{\circ} \mathrm{C}$ & $2.99 b$ & $2.32 b$ & $3.02 b c$ & $2.53 \mathrm{~s}$ & $3.12 \mathrm{a}$ & & 0.045 \\
\hline & $10^{\circ} \mathrm{C}$ & $2.99 b$ & $2.52 \mathrm{~b}$ & $3.58 \mathrm{ab}$ & & & & 0.308 \\
\hline & $20^{\circ} \mathrm{C}$ & $2.99 \mathrm{~b}$ & $2.46 \mathrm{~b}$ & & & & & \\
\hline \multirow{12}{*}{ 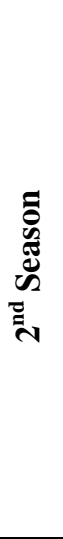 } & Coratina & & & & & & & \\
\hline & $5^{\circ} \mathrm{C}$ & $4.03 \mathrm{a}$ & $2.19 \mathrm{c}$ & $2.93 \mathrm{a}$ & $2.84 \mathrm{~b}$ & $2.95 \mathrm{~b}$ & 3.11 & 0.047 \\
\hline & $10^{\circ} \mathrm{C}$ & $4.03 \mathrm{a}$ & $2.47 b c$ & $3.28 \mathrm{a}$ & $2.25 \mathrm{c}$ & & & 0.518 \\
\hline & $20^{\circ} \mathrm{C}$ & $4.03 \mathrm{a}$ & $2.66 b c$ & & & & & \\
\hline & Manzanillo & & & & & & & \\
\hline & $5^{\circ} \mathrm{C}$ & $3.57 \mathrm{ab}$ & $3.32 b$ & $2.99 \mathrm{a}$ & $3.18 \mathrm{~b}$ & & & 0.629 \\
\hline & $10^{\circ} \mathrm{C}$ & $3.57 \mathrm{ab}$ & $4.62 \mathrm{a}$ & $3.17 \mathrm{a}$ & & & & 0.071 \\
\hline & $20^{\circ} \mathrm{C}$ & $3.57 \mathrm{ab}$ & $4.52 \mathrm{a}$ & & & & & \\
\hline & Picual & & & & & & & \\
\hline & $5^{\circ} \mathrm{C}$ & $2.66 \mathrm{~b}$ & $2.06 \mathrm{c}$ & $2.74 \mathrm{a}$ & $3.98 \mathrm{a}$ & $4.11 \mathrm{a}$ & & 0.726 \\
\hline & $10^{\circ} \mathrm{C}$ & $2.66 \mathrm{~b}$ & $2.28 b c$ & $3.64 \mathrm{a}$ & & & & 0.488 \\
\hline & $20^{\circ} \mathrm{C}$ & $2.66 \mathrm{~b}$ & $3.02 \mathrm{bc}$ & & & & & \\
\hline
\end{tabular}

Means within columns (in same season) having a common letter are not significantly different.

$\mathrm{r}^{2}=$ Determination coefficient

Arachidic acid percent was less than $1 \%$ in all cvs where as an average of two seasons Coratina contained $0.512 \%$, Manzanillo contained $0.583 \%$ and Picual contained $0.610 \%$ (table 8 ). Those initial contents declined by the end of the storage period and there was no significant effect of storage temperature on arachidic content of all olive cvs in this work. Agar et al., (1999) reported that arachidic acid content of black-ripe Manzanillo declined from $0.9 \%$ at harvest to between 0.2 and $0.7 \%$ irrespective of storage temperature and atmosphere.

Olive fruits of Carotina, Manzanillo and Picual contained as an average of the two seasons 0.195, 0.197 and $0.169 \%$ of myristic acid (table 9) which increased in Coratina fruits which were stored at $10{ }^{\circ} \mathrm{C}$ in the two seasons. Also, myristic acid increased by the progress of the storage time.

\section{b- Unsaturated fatty acids:}

The total unsaturated fatty acids of Coratina, Manzanillo and Picual olives were 76.06, 74.77 and
$76.37 \%$, respectively in the first season and were 73.46 , 74.23 and $74.44 \%$ in the second one.

At harvest, Coratina, Manzanillo and Picual olives contained (an average of two seasons) 65.02, 63.12 and $65.90 \%$ of oleic (monounsaturated) acid (table 10). Those percentages were not affected by the storage temperature but generally the fruits that were stored at $5^{\circ} \mathrm{C}$ contained higher percents. Oleic acid contents declined with the progress of the storage period $\left(\mathrm{r}^{2}\right.$ values were not significant). Agar et al., (1998) recorded that the average oleic acid content of Mission olives was $73 \%$, that of Sevillano and Manzanillo olives was $69 \%$ and Ascolano olives contained $63.5 \%$ oleic acid after 6 and 8 weeks at $5^{\circ} \mathrm{C}$. A high concentration of oleic acid enhances the stability of the oil, and a diet rich in this fatty acid reduces cholesterol levels. On the other hand, Ager et al., (1999) reported that oleic acid (66.1-70.4\%) is the main monounsaturated fatty acid in olives which also contain low amounts of palmitoleic acid (1.3-1.9\%). 


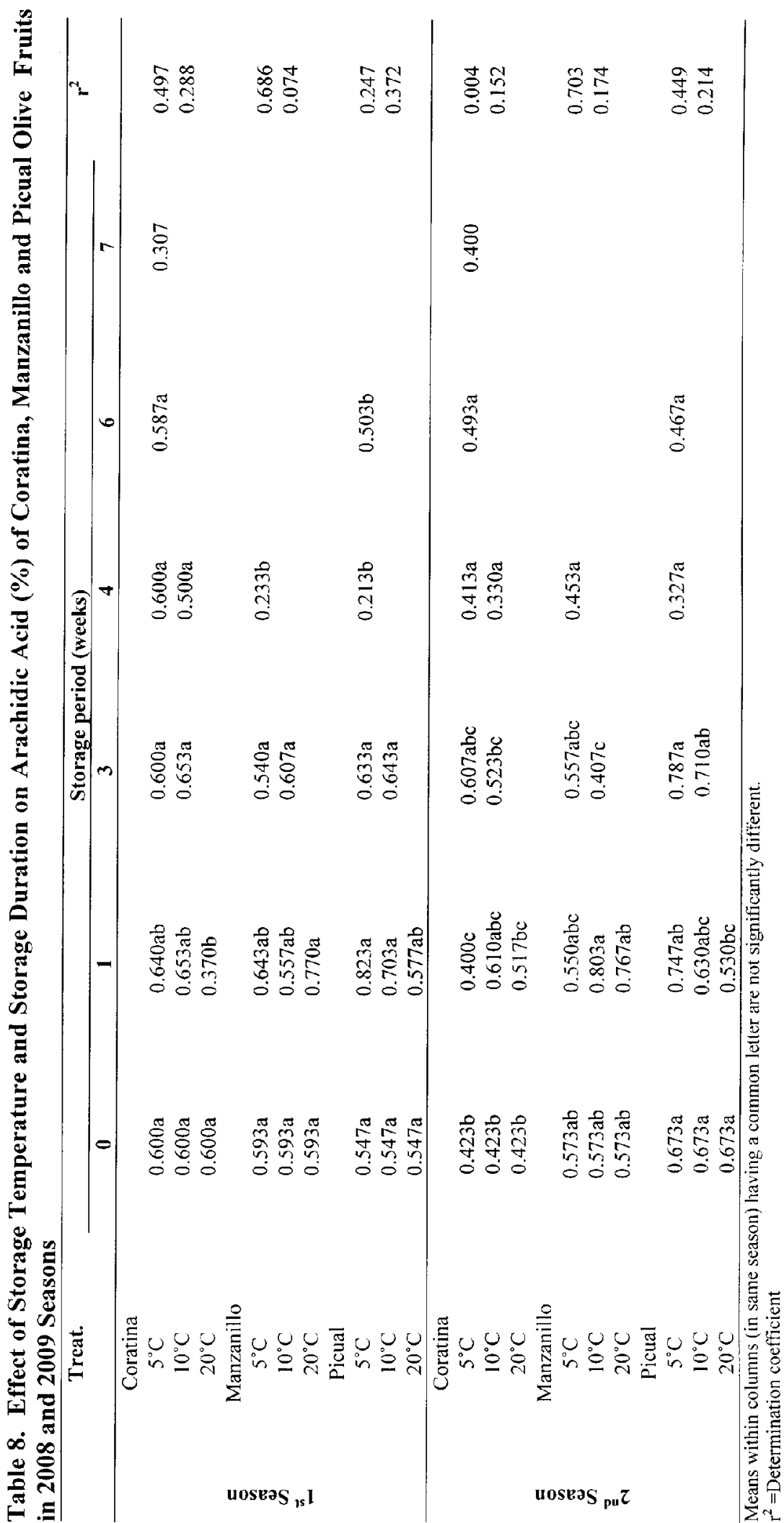




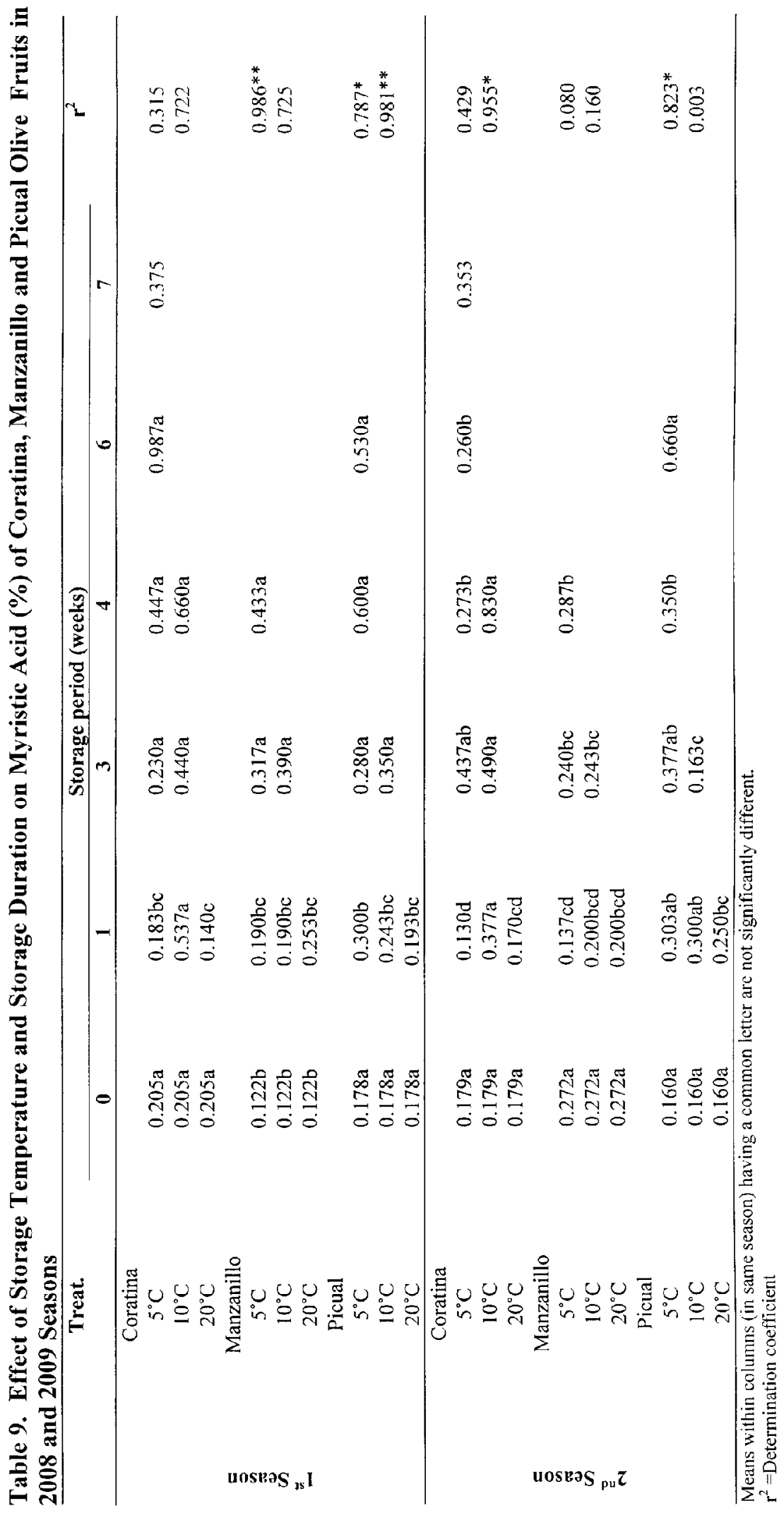


Table 10. Effect of Storage Temperature and Storage Duration on Oleic Acid (\%) of Coratina, Manzanillo and Picual Olive Fruits in 2008 and 2009 Seasons

\begin{tabular}{|c|c|c|c|c|c|c|c|c|}
\hline & \multirow[t]{2}{*}{ Treat. } & \multicolumn{6}{|c|}{ Storage period (weeks) } & \multirow[t]{2}{*}{$\mathbf{r}^{2}$} \\
\hline & & 0 & 1 & 3 & 4 & 6 & 7 & \\
\hline \multirow{12}{*}{ 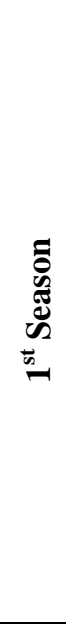 } & Coratina & & & & & & & \\
\hline & $5^{\circ} \mathrm{C}$ & $66.51 \mathrm{a}$ & $64.47 \mathrm{a}$ & $64.34 \mathrm{a}$ & $65.81 \mathrm{a}$ & $62.32 \mathrm{a}$ & 64.70 & 0.272 \\
\hline & $10^{\circ} \mathrm{C}$ & $66.51 \mathrm{a}$ & $62.01 \mathrm{a}$ & $60.38 \mathrm{a}$ & $63.73 \mathrm{a}$ & & & 0.241 \\
\hline & $20^{\circ} \mathrm{C}$ & $66.51 \mathrm{a}$ & $65.19 a$ & & & & & \\
\hline & Manzanillo & & & & & & & \\
\hline & $5^{\circ} \mathrm{C}$ & $62.89 \mathrm{a}$ & $64.29 a$ & $63.41 \mathrm{a}$ & $64.04 \mathrm{a}$ & & & 0.276 \\
\hline & $10^{\circ} \mathrm{C}$ & $62.89 a$ & $64.31 \mathrm{a}$ & $62.07 \mathrm{a}$ & & & & 0.131 \\
\hline & $20^{\circ} \mathrm{C}$ & $62.89 \mathrm{a}$ & $62.03 \mathrm{a}$ & & & & & \\
\hline & Picual & & & & & & & \\
\hline & $5^{\circ} \mathrm{C}$ & $66.55 a$ & $68.29 a$ & $63.66 \mathrm{a}$ & $63.82 \mathrm{a}$ & $62.60 \mathrm{a}$ & & 0.690 \\
\hline & $10^{\circ} \mathrm{C}$ & $66.55 \mathrm{a}$ & $65.33 \mathrm{a}$ & $60.82 \mathrm{a}$ & & & & 0.790 \\
\hline & $20^{\circ} \mathrm{C}$ & $66.55 \mathrm{a}$ & $63.47 \mathrm{a}$ & & & & & \\
\hline \multirow{12}{*}{ 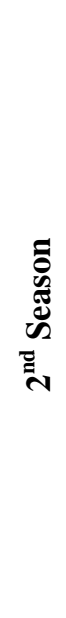 } & Coratina & & & & & & & \\
\hline & $5^{\circ} \mathrm{C}$ & $63.52 \mathrm{a}$ & $67.58 \mathrm{a}$ & $62.91 \mathrm{abc}$ & $60.57 \mathrm{a}$ & $62.03 \mathrm{a}$ & 59.52 & 0.548 \\
\hline & $10^{\circ} \mathrm{C}$ & $63.52 \mathrm{a}$ & $65.61 \mathrm{a}$ & $60.19 b c$ & $62.74 \mathrm{a}$ & & & 0.200 \\
\hline & $20^{\circ} \mathrm{C}$ & $63.52 \mathrm{a}$ & $66.10 \mathrm{a}$ & & & & & \\
\hline & Manzanillo & & & & & & & \\
\hline & $5^{\circ} \mathrm{C}$ & $63.35 \mathrm{a}$ & $59.01 b c$ & 63.38abc & $63.29 \mathrm{a}$ & & & 0.062 \\
\hline & $10^{\circ} \mathrm{C}$ & $63.35 \mathrm{a}$ & $59.22 b c$ & $66.03 \mathrm{a}$ & & & & 0.153 \\
\hline & $20^{\circ} \mathrm{C}$ & $63.35 \mathrm{a}$ & $57.85 \mathrm{c}$ & & & & & \\
\hline & Picual & & & & & & & \\
\hline & $5^{\circ} \mathrm{C}$ & $65.24 \mathrm{a}$ & $64.35 \mathrm{ab}$ & $64.55 \mathrm{ab}$ & $63.61 \mathrm{a}$ & $59.10 \mathrm{~b}$ & & 0.702 \\
\hline & $10^{\circ} \mathrm{C}$ & $65.24 \mathrm{a}$ & $63.96 \mathrm{abc}$ & $58.39 \mathrm{c}$ & & & & 0.684 \\
\hline & $20^{\circ} \mathrm{C}$ & $65.24 \mathrm{a}$ & $58.98 b c$ & & & & & \\
\hline
\end{tabular}

Means within columns (in same season) having a common letter are not significantly different.

$\mathrm{r}^{2}=$ Determination coefficient

Olives contained low percentage of palmitoleic (monounsaturated) acid (table 11) which were at harvest (as an average of two seasons) 1.81, 2.31 and $1.83 \%$ in Coratina, Manzanillo and Picual fruits, respectively. Those initial values were not affected by the storage temperature and increased with the end of the storage time ( $\mathrm{r}^{2}$ values were not significant).

Manzanillo olives contained the highest initial percents (an average of two seasons) of linoleic (polyunsaturated) acid (7.09\%) compared with Coratina $(5.65 \%)$ and Picual $(5.02 \%)$ fruits (table 12). The above percentages increased with the progress of the storage period $\left(\mathrm{r}^{2}\right.$ values were significant only in Coratina fruits in the second season) and were not affected by storage temperature.
On the other hand, the initial contents (an average of two seasons) of linolenic (polyunsaturated) acid were $1.71 \%$ in Coratina, $2.09 \%$ in Manzanillo and $2.09 \%$ in Picual (table 13). Linolenic acid was affected slightly by storage time ( $\mathrm{r}^{2}$ values were not significant) and was not affected by storage temperature. Linolenic acid content of Coratina fruits increased in the third week at 5 and $10^{\circ} \mathrm{C}$ then decreased with the progress of the storage period. Coratina had the highest linolenic content at the third week while Manzanillo had the highest content after 4 weeks at $5^{\circ} \mathrm{C}$. Agar et al., (1999) recorded that polyunsaturated fatty acids are very important for human nutrition as they are considered essential. Linoleic acid was the dominant polyunsaturated fatty acid in Manzanillo olives ranging 
from 9.1 to $11.5 \%$, while linolenic acid ranged from

0.9 to $1.4 \%$. Raina, (1995)

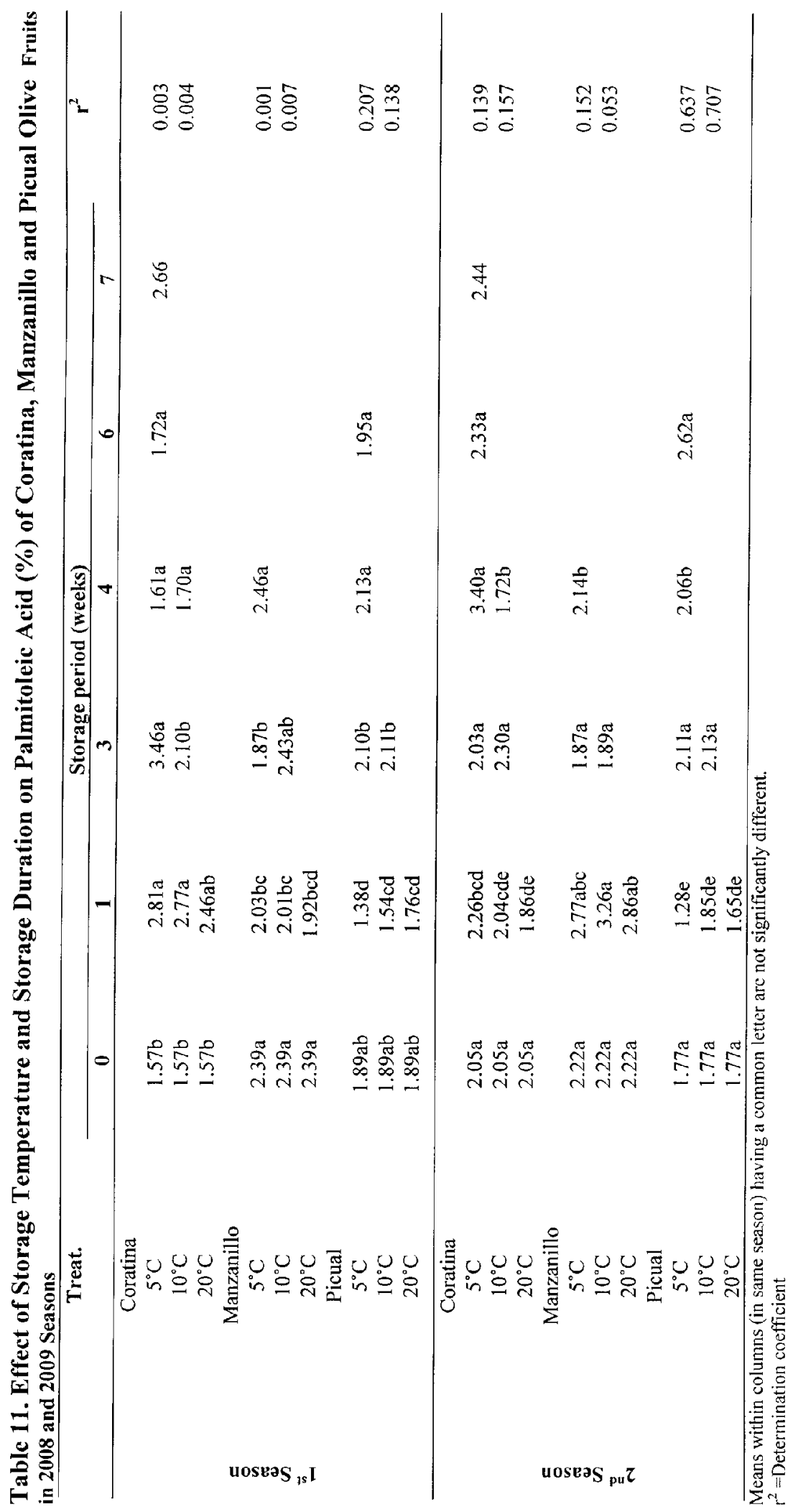




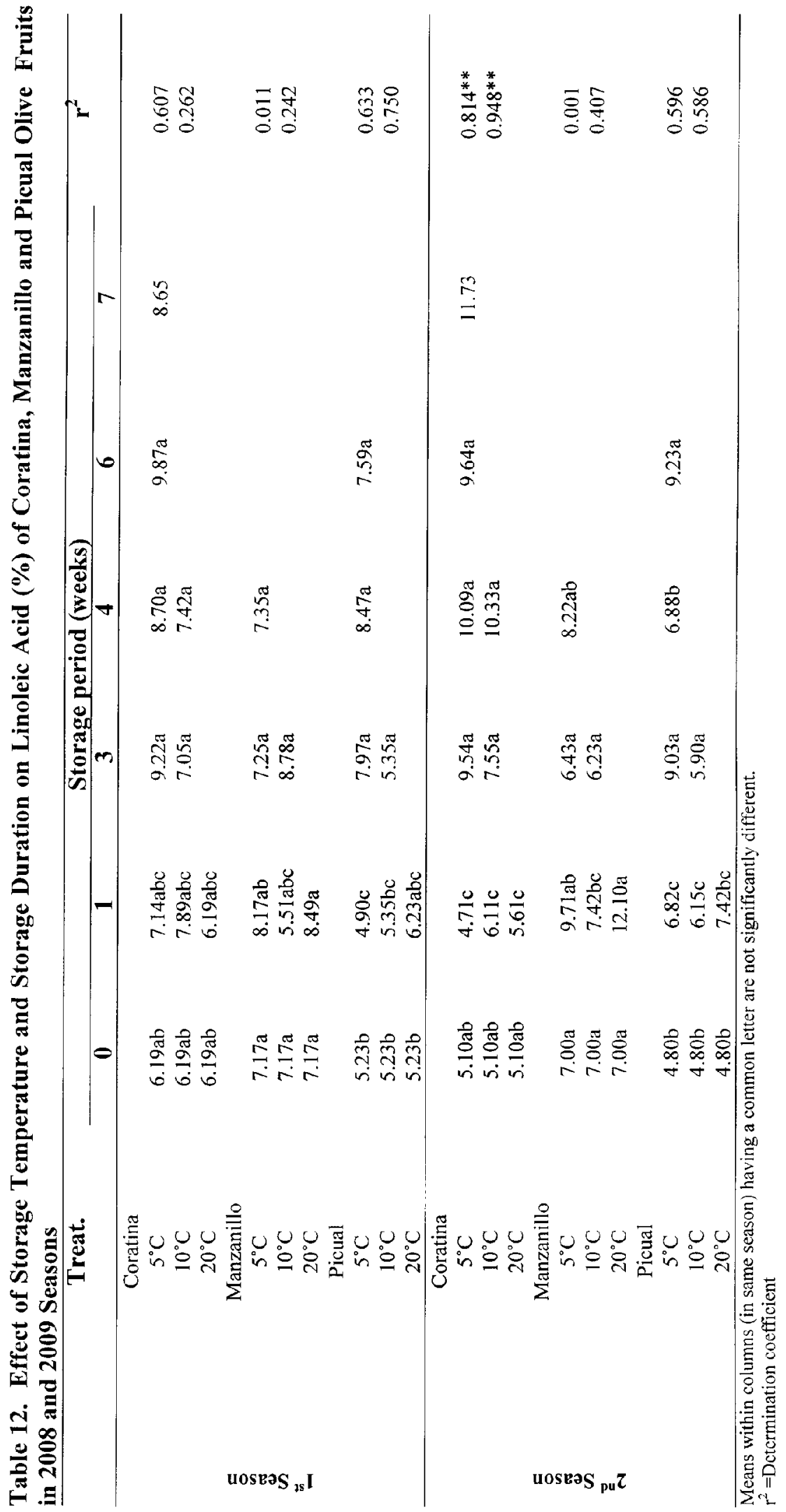




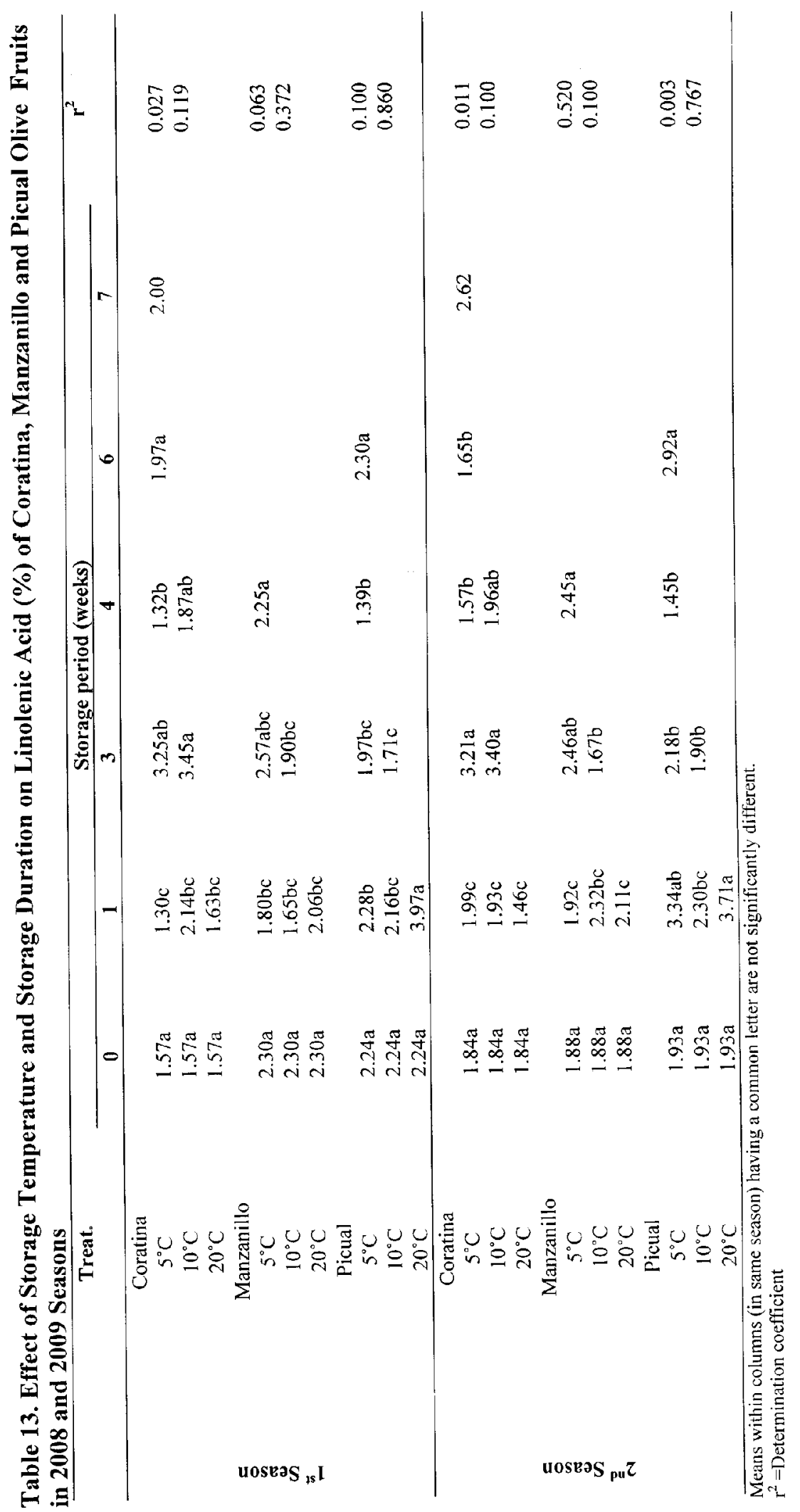


Table 14. Effect of Storage Temperature and Storage Duration on Lipids Content (\%) of Coratina, Manzanillo and Picual Olive Fruits in 2008 and 2009 Seasons

\begin{tabular}{|c|c|c|c|c|c|c|c|c|}
\hline & Treat. & & & Storage & d (weeks) & & & $\mathbf{r}^{2}$ \\
\hline & & $\mathbf{0}$ & 1 & 3 & 4 & 6 & 7 & \\
\hline & Cortina & & & & & & & \\
\hline & $5^{\circ} \mathrm{C}$ & $26.03 b$ & $27.34 \mathrm{a}$ & $26.18 \mathrm{a}$ & $27.58 \mathrm{a}$ & $25.43 b$ & 25.74 & 0.124 \\
\hline & $10^{\circ} \mathrm{C}$ & $26.03 \mathrm{~b}$ & $25.99 \mathrm{a}$ & $26.52 \mathrm{a}$ & $26.18 \mathrm{a}$ & & & 0.006 \\
\hline & $20^{\circ} \mathrm{C}$ & $26.03 b$ & $27.30 \mathrm{a}$ & & & & & \\
\hline & Manzanillo & & & & & & & \\
\hline$\Phi$ & $5^{\circ} \mathrm{C}$ & $27.91 \mathrm{a}$ & $27.00 \mathrm{a}$ & $25.73 a$ & $27.82 \mathrm{a}$ & & & 0.039 \\
\hline 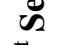 & $10^{\circ} \mathrm{C}$ & $27.91 \mathrm{a}$ & $26.62 \mathrm{a}$ & $26.12 \mathrm{a}$ & & & & 0.096 \\
\hline$\stackrel{n}{n}$ & $20^{\circ} \mathrm{C}$ & $27.91 \mathrm{a}$ & $26.92 \mathrm{a}$ & & & & & \\
\hline & Picual & & & & & & & \\
\hline & $5^{\circ} \mathrm{C}$ & $27.04 \mathrm{~b}$ & $26.93 \mathrm{a}$ & $25.99 \mathrm{a}$ & $26.37 \mathrm{a}$ & $28.93 \mathrm{a}$ & & 0.201 \\
\hline & $10^{\circ} \mathrm{C}$ & $27.04 \mathrm{~b}$ & $25.30 \mathrm{a}$ & $26.21 \mathrm{a}$ & & & & 0.596 \\
\hline & $20^{\circ} \mathrm{C}$ & $27.04 \mathrm{~b}$ & $26.38 \mathrm{a}$ & & & & & \\
\hline & Cortina & & & & & & & \\
\hline & $5^{\circ} \mathrm{C}$ & $25.95 \mathrm{a}$ & 25.96ab & $24.60 \mathrm{a}$ & 27.99ab & $25.58 \mathrm{a}$ & 24.67 & 0.113 \\
\hline & $10^{\circ} \mathrm{C}$ & $25.95 \mathrm{a}$ & $27.02 \mathrm{ab}$ & $25.79 \mathrm{a}$ & $26.27 \mathrm{~b}$ & & & 0.004 \\
\hline & $20^{\circ} \mathrm{C}$ & $25.95 \mathrm{a}$ & $27.61 \mathrm{ab}$ & & & & & \\
\hline & Manzanillo & & & & & & & \\
\hline$\tilde{\Phi}$ & $5^{\circ} \mathrm{C}$ & $26.92 \mathrm{a}$ & $28.70 \mathrm{a}$ & $26.23 \mathrm{a}$ & $29.71 \mathrm{a}$ & & & 0.227 \\
\hline$\tilde{n}$ & $10^{\circ} \mathrm{C}$ & $26.92 a$ & $27.52 \mathrm{ab}$ & $25.78 \mathrm{a}$ & & & & 0.416 \\
\hline$\stackrel{\sim}{ }$ & $20^{\circ} \mathrm{C}$ & $26.92 \mathrm{a}$ & $26.78 \mathrm{ab}$ & & & & & \\
\hline & Picual & & & & & & & \\
\hline & $5^{\circ} \mathrm{C}$ & $27.19 \mathrm{a}$ & 26.33ab & $26.35 \mathrm{a}$ & $26.44 \mathrm{~b}$ & $25.08 \mathrm{a}$ & & 0.734 \\
\hline & $10^{\circ} \mathrm{C}$ & $27.19 \mathrm{a}$ & $25.13 b$ & $27.69 \mathrm{a}$ & & & & 0.034 \\
\hline & $20^{\circ} \mathrm{C}$ & $27.19 \mathrm{a}$ & $24.97 \mathrm{~b}$ & & & & & \\
\hline
\end{tabular}

Means within columns (in same season) having a common letter are not significantly different.

$r^{2}=$ Determination coefficient

said that the maximum limit allowed by IOOC (International Olive Oil Council) in extra olive oil is 0.9 $\%$ linolenic acid.

\section{Lipids:}

At harvest, total lipids content of Coratina were 26.03 and $25.95 \%$, of Manzanillo were 27.91 and 26.92 $\%$ and that of Picual were 27.04 and $27.19 \%$, respectively in 2008 and 2009 seasons (table 14). There was no effect of storage temperature on lipids content of the three cvs but generally, the fruits that were stored at $20^{\circ} \mathrm{C}$ contained lower values than those at 5 and $10^{\circ} \mathrm{C}$. There was no significant change in total lipid percent during the cold storage period where $r^{2}$ values were not significant.

As a conclusion, in the present work it is recommended that Carotina, Manzanillo and Picual olive fruits should not be stored more than 4 weeks at $5^{\circ} \mathrm{C}$ to avoid the chilling injury, the loss of oil content and the increasing of linolenic acid. Also, olive fruits should not be stored at $10^{\circ} \mathrm{C}$ for more than 2 weeks where the fruits could loss more than $25 \%$ of its oil content.

\section{ACKNOWLEDGEMENT}

The author wish to express her thanks to the Alexandria Post-harvest Center, Pomology Department, Faculty of Agriculture (El-Shatby), Alexandria University for providing the necessary facilities, help and encouragement during the course of this work

\section{REFERENCES}

Agar, I. T.; B. H. Pierce; M. M. Sourour and A. A. Kader (1998). Quality of fruit and oil of black-ripe olives is influenced by cultivar and storage period. J. Agric. Food Chem., 46: 3415-3421.

Agar, I. T.; B. H. Pierce; M. M. Sourour and A. A. Kader (1999). Identification of optimum preprocessing storage condition to maintain quality of black ripe Manzanillo olives. Posth. Bio. and Techn., 15 (53): 53-64.

AOAC (1984). Official methods of analysis of the association of official analytical chemists, Sidney Williams. $14^{\text {th }}$ ed. Association of official analytical chemists, INC. Arlington, Virginia 22209 U.S.A.

Castellano, J.M.; J.M. Garcia; A. Morilla; S. Perdiguero and F. Gutierrez (1993). Quality of Picual olive fruits under 
controlled atmosphere. J. Agric. And Food Chem., 41: 537-539.

Clodoveo, M. L.; D. Delcuratolo; T. Gomes and G. Colelli (2007). Effect of different temperature and storage atmospheres on Coratina olive oil quality. Food Chem., 102 (3): 571-576.

Folch, J.; M. Lees and G. Sloane-Stanly (1957). Techniques of lipidology. J. Biol-Chem., 226, 497 (c.f. Kates, M., 1972). North-Holland/American Elsevier).

Garcia, J. M. and J. Streif (1991). The effect of controlled atmosphere storage on fruit quality of Gordal olives. Gartenbauwissenschaft, 56: 233-238.

Garcia, J. M. and K. Yousfi (2006). The postharvest of mill olives. Grasas Y Aceites, 57 (1): 16-24.

Garcia, J. M.; F. Gutierrez; J. M. Castellano; S. Perdiguero and M. A. Albi (1996). Influence of storage temperature on fruit ripening and olive oil quality. J. Agric. Food Chem., 44: 264-267.

Gutierrez, F.; S. Perdiguero; J. M. Garcia and J. M. Castellano (1992). Quality of oils from olives stored under controlled atmosphere. J. Am. Oil Chem. Soc., 69: 1215-1218.

Kader, A. A. (1985). An overview of the physiological and biochemical basis of CA effects on fresh horticultural crops. In: Controlled atmospheres for storage and transport of perishable agricultural commodities. Fourth Nat. Contr. Atm. Res. Conf. North Carolina State Univ. pp:1-9.

Kader, A. A. (1996). Olive disorders. University of California Perishables Handling Newsletter86; University of California, Los Angeles,CA, pp. 8-9.

Kader, A. A.; G. D. Nanos and E. L. Kerbel (1989). Responses of Mazanillo olives to controlled atmosphere storage. In Proceeding of the $5^{\text {th }}$ International Controlled Atmosphere Research Conference, Washington State University: Wenatchee, Wa, Vol. 2 pp: 119-125.

Kader, A.A.; G.D. Nanos and E.L. Kerbel (1990). Storage potential of fresh Nanzanillo olived. California Agric., 40 (3): 23-24.

Kiritsakis, A.; G. D. Nanos; Z. Polymenopoulos; T. Thomani and E. M. Sfakiotakis (1998). Effect of fruit storage conditions on olive oil quality. J. Amer. Oil Chem. Soc., 75(6): 721-732.

Maxie, E. C.(1998). Experiments on cold storage and controlled atmosphere. In the $43^{\text {th }}$ Annual technical Report of the California Olive Association, Davis, CA, pp:12-15.

McGuire, R. G. (1992). Reporting of objective color measurements. HortScience, 27: 1254-1255.

Mclellan, M. R.; L. R. Lind and R. W. Kime (2007). Hue angle determinations and statistical analysis for multiquadrant hunter L, a, b data. J. Food Quality, 18 (3): 235-240.

Olias, J. M. and J. M. Garcia (1997). In postharvest physiology and storage of tropical and subtropical fruits, Mitra, S. K.; Ed., CAB International: Wallingford, U. K., pp: 229-243.

Ozturk, I.; S. Ercisli and M. Kara (2009). Chosen physical properties of olive cultivars (Olea europaea L). Int. Agrophysics, 23: 309-312.

Petruccioli, G. and M. V. Parlati (1987). Studies on olives storage before oil extraction. III. Effect of storage conditions of olives on the chemical and organoleptic characteristics of oils. In Third subproject: Conservation and processing of foods. A research report, Natiopnal Council of Italy: Milano, Abstract 20, pp 83-84.

Radwan, S. S. (1978). Coupling of two dimensional thin layer chromatography with gas chromatography for the quantitative analysis of lipids classes and constituent fatty acids. J. Chromato. Sci., 16:538-542.

Raie, M. Y. and I. Latif (1982). Physicochemical characteristics and free fatty acid content of olive fruits stored under different conditions. Pakistan J. Sci. \& Indus. Res., 25: 64-65.

Raina, B. (1995). Olive. In: Salunkhe, D. K. and S.S. Kadam (Eds.), Handbook of Fruit Science and Technology, Production, Composition, Storage and Processing. Marcel Dekker, New York, pp 465-473.

SAS (1985). SAS user' guide statistics for personal computers version $5^{\text {th }}$ ed. SAS Inst. Cary NCO.

Snedecor, G. W. and W. G. Cochran (1980). Statistical Methods. $7^{\text {th }}$ Ed., $4^{\text {th }}$ Printing, the Iowa State Univ. Press Ames., Iowa U. S. A. 


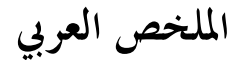

\section{تأثير درجة حرارة التخزين و مدته على جودة ثمار وزيت الزيتون أصناف كوراتينا و مانز انيللو وبيكو ال}

نرمين اسماعيل النجار، رجاء موسى الصعيدى

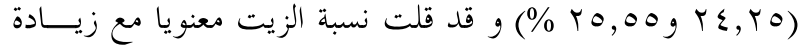

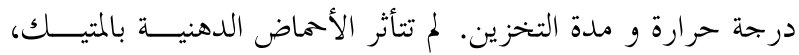
أراكيديك، أوليك، بالميتوليك و لينوليك بدرجة حرارة التخهـزين.

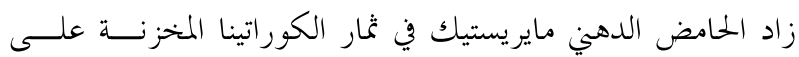

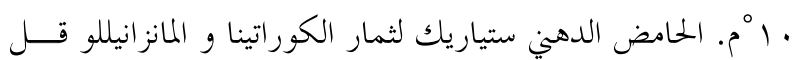
مع هاية مدة التخزين بينما زاد في ثمار البيكوال. الأحماض الدهنيــة مايريستيك، بالميتوليك و لينوليك زادت مع تقدم فترة التخزين بينما

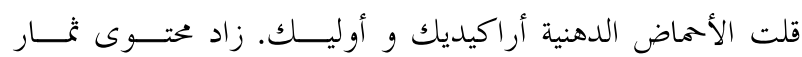

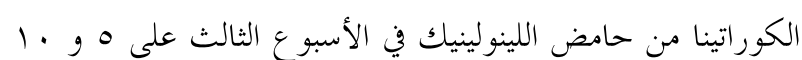

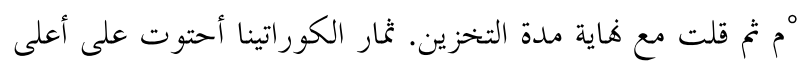

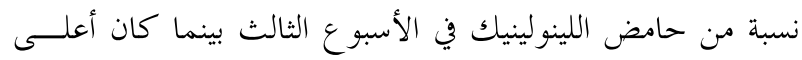

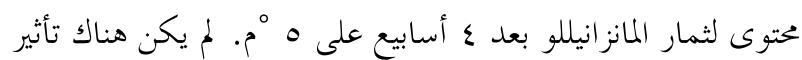
لدرجة حرارة التخزين و مدته على محتوي الثمار من الدهون الكلية لكن بوجه عام أحتوت الثمار المخزنة على . بَّم على أقل محتوى.

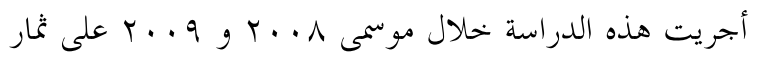
الزيتون أصناف كوراتينا، مانزانيللو و بيكوال. تم تخزين الثمار على

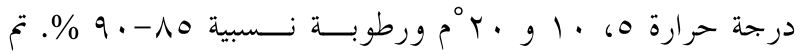

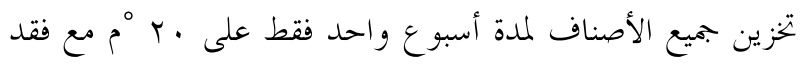

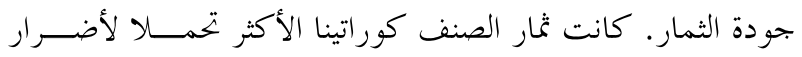
البرودة و لم يلاحظ تكون لون بني في لحم الثماربلميع الأصــناف

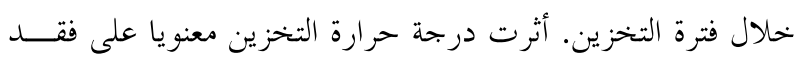

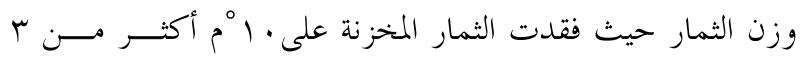
أضعاف تلك المخزنة على هْْْم. زاد فقد وزن الثمار مع تقدم فترة

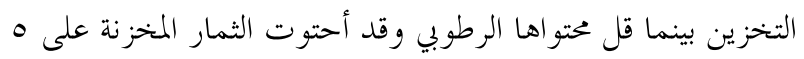

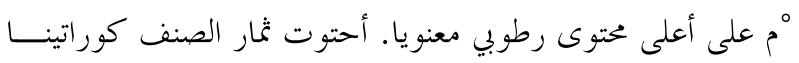

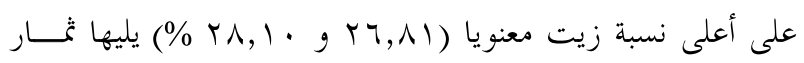

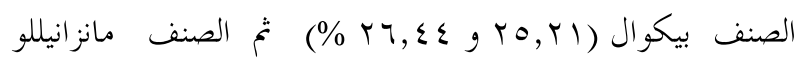

